\title{
Immunisering van pasgeborenes teen hepatitis $B$
}

Endemiese hepatitis B is 'n ernstige gesondheidsprobleem in KaNgwane, tuiste van Suid-Afrika se Swazi's. ${ }^{1}$ Besmetting met die hepatitis B-virus (HBV) is so algemeen in hierdie gemeenskap en vind alreeds so vroeg in die lewe plaas dat inenting van pasgeborenes regverdigbaar en wenslik is. ${ }^{1}$ Horisontale oordrag van HBV gedurende die eerste lewensjare speel ' $n$ baie groter rol in die infeksiepatroon as perinatale oordrag, ${ }^{1-7}$ sodat wydverspreide inenting van jong babas waarskynlik 'n goeie metode is om die siekte onder beheer te kry.' 'n Beperkte inentingsproef in Senegal met geïnaktiveerde, aluingeadsorbeerde entstof van die Pasteurinstituut ${ }^{8}$ het goeie resultate gelwer, sonder inagneming van die HBVmerkers van moeders en hulle babas. ${ }^{6}$ As deel van 'n groter ondersoek om die vergelykbare immuunreaksie en aanvaarbaarheid van die Merck HBV-entstof ${ }^{9}$ in suigelinge van verskillende ouderdomme te bepaal, is 73 pasgeborenes geïmmuniseer en vir 9 maande opgevolg.

Die entstof was formaliengeïnaktiveerde, met pepsien en ureum behandelde, aluingeadsorbeerde Merck-entstof wat van virusdraers se bloedplasma berei is. ${ }^{9}$ Die vervaardigingspoelnommer was 751 en die antigeniese subtipe ad..$^{9}$ Die entstof is toegedien as 3 onafhanklike intramuskulêre inspuitings van $0,5 \mathrm{ml}$ (10 mikrogram per dosis). Die eienskappe van HBV- merkerstatus van die moeders en babas net voor die eerste dosistoediening verskyn in tabel 1 .

Die inspuitings is toegedien in die eerste week na geboorte (D1), na een maand (D2) en op sesmaandeouderdom (D3). Moeders en babas het armbande ontvang om identifisering en opvolging te vergemaklik. Klinieksusters het elke baba daagliks vir 5 dae na elke inspuiting ondersoek om moontlike neweeffekte spoedig op te spoor. Enige onverwagte bevinding is dan by die toesighoudende geneesheer aange-

TABEL 1

Eienskappe van 73 pasgeborenes voor eerste dosis

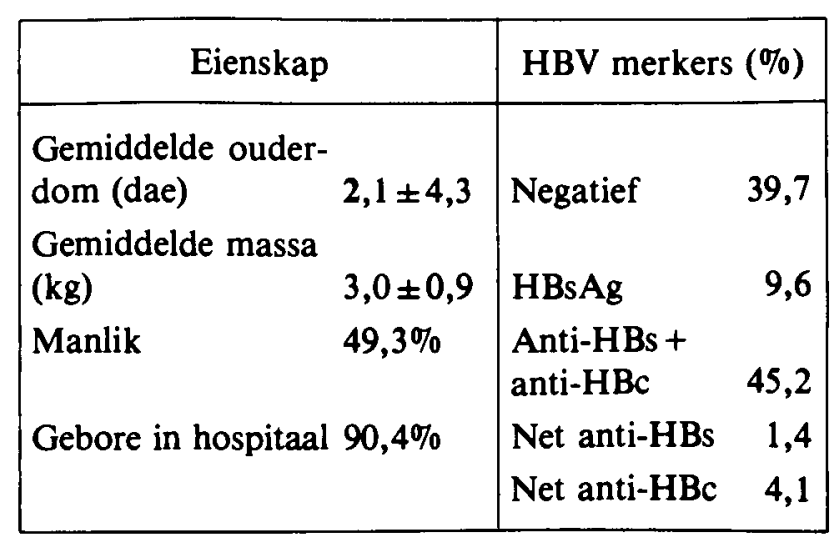


ANTI-HBS NEGATIEF

(GEBOORTE (AANTAL=29)

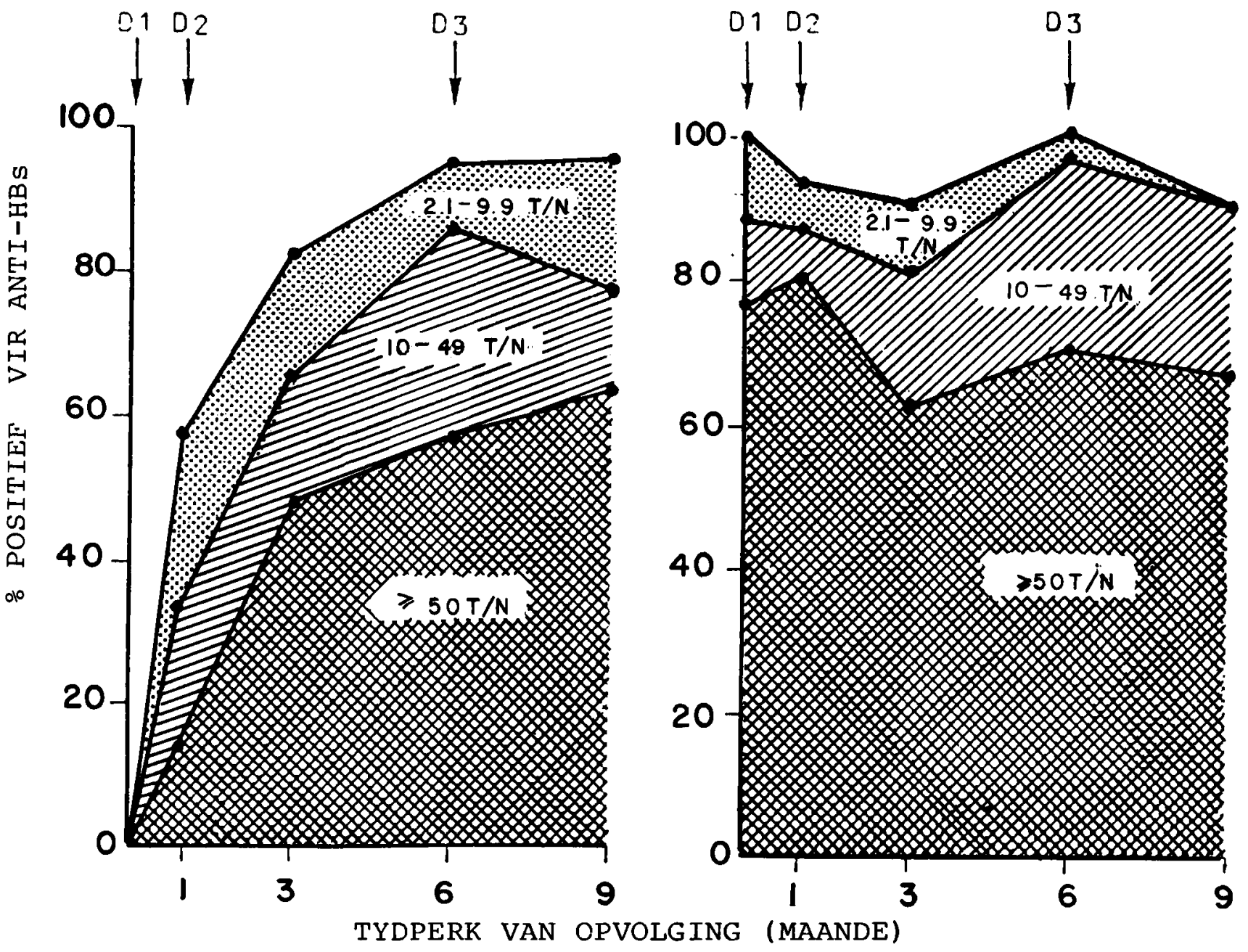

足
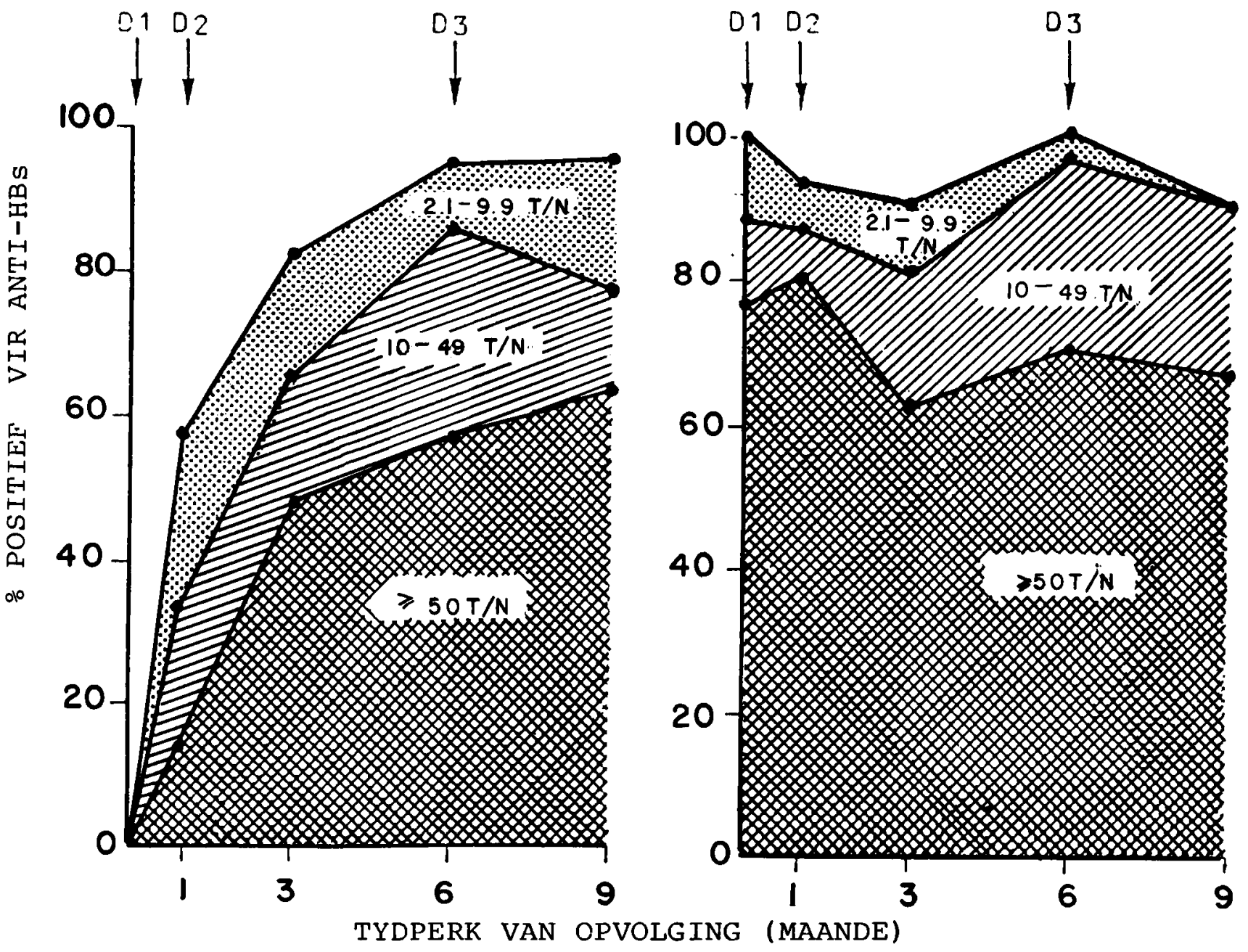

ANTI-HBS POSITIEF

BY GEBOORTE (AANTAL $=34$ )

$\mathrm{T} / \mathrm{N}=$ WAARDE VAN TOETSMONSTER/WAARDE VAN NEGATIEWE KONTROLE

FIGUUR 1: Anti-HBs in pasgeborenes na inenting met Merck hepatitis B-entstof.

meld vir verdere optrede of ondersoek, indien nodig, Veneuse bloedmonsters is van die babas en die moeders net voor die eerste dosistoediening verkry, sowel as van die babas op 1, 3, 6 en 9 maande. Die HBV-merkers in die bloedserum is bepaal deur radioimmuuntoetse (Abbott, Chicago).

Die onderskeidelike resultate van die immuunreaksies van die groep babas wat negatief was vir alle merkers met die eerste dosis en dié wat anti-HBs positief was, word uitgebeeld in figuur 1. Alle moeders van die anti-HBs positiewe suigelinge was ook anti-HBs positief, wat aandui dat hierdie suigelinge die teëliggame transplasentaal vanaf die moeders verkry het (passiewe immuniteit). ${ }^{1}$ Van die 29 HBV-merker negatiewe suigelinge het $28(96,6 \%)$ teëliggame te wyte aan die entstof op 9 maande getoon. Die 34 anti-HBs positiewe suigelinge het effens swakker gereageer, met $31(91,2 \%)$ positief op 9 maande. Statistiese analise toon egter dat die verskil nie betekenisvol is nie en lukraak mag wees. ${ }^{9}$ Die groep wat teëliggaam positief by geboorte was, het 'n geringe daling van teëliggaampositiwiteit na 3 maande getoon, gevolg deur 'n styging te wyte aan die entstof, terwyl die merker negatiewe groep net 'n deurgaande styging te wyte aan immunisering getoon het. Na 9 maande was die persentasie individue met hoë anti-HBs-peile (meer as $50 \mathrm{~T} / \mathrm{N}$ ) ongeveer dieselfde in die merker positiewe en die merker negatiewe groep, terwyl babas met gemiddelde antiliggaampeile (10-49 T/N) meer in die merker positiewe groep voorgekom het. Weereens was die verskille tussen die groepe na 9 maande uiters gering (Figuur 1).

Die enigste ongewenste newe-effekte wat aan die entstof gewyt kon word, was 'n ligte temperatuurverhoging by 3\% van die babas wat met elke dosis voorgekom het. Geeneen van die babas het te enigertyd kliniese of biochemiese tekens van lewerontsteking getoon nie.

Die 10 mikrogramdosis wat in hierdie ondersoek gebruik is, is as hoogs immunogenies bevind, alhoewel enkele nie-reagerende individue weer teëgekom is, soos in vorige ondersoeke by andersoortige persone met hierdie entstof ${ }^{9}$ en met ander 
entstowwe.9, 6 Die eindresultaat op 9 maande was dus baie bevredigend en onafhanklik van die merkerstatus van die pasgeborene of sy moeder, 'n feit wat uiters belangrik is wanneer massa-inentingsprogramme beoog en uitgevoer word. Verder het die entstof slegs baie geringe newe-effekte veroorsaak en het dit, selfs by pasgeborenes, veilig geblyk. Wanneer die entstof, soos binnekor: verwag, goedkoper en vryliker beskikbaar word, ${ }^{10}$ sal dit met vrymoedigheid selfs by pasgeborenes gebruik kan word in die endemiese gebiede waar dit die meeste nodig is.

\section{O.W. PROZESKY}

Afdeling Virologie, Departement Geneeskundige Virologie, Universiteit van Pretoria, Posbus 2034, Pretoria, en Nasionale Instituut vir Virologie, Edenvale.

CLADD E. STEVENS, W. SZMUNESS, H. ROLKA, E.J. HARLEY

Lindsley F. Kimball-Navorsingsinstituut van die New York Blood Center, 310 East 67th Street, New York. 10021

\section{M.C. KEW}

Departement Interne Geneeskunde, Fakulteit Geneeskunde, Universiteit van die Witwatersrand, Johannesburghospitaal, Johannesburg 2001

\section{J.E.R. SCHOLTZ, A.D. MITCHELL}

Themba- en Shongwehospitale, Departement van

Gesondheid van KaNgwane, Louws' Creek 1302.

\section{VERWYSINGS}

1. Prozesky, O.W. et al. (1982). Bepaling van die Hepatitis B-infeksiepatroon in 'n landelike Swart gemeenskap voor inenting, S. Afr. Tydskr. Nat. Tegn., 2, 8-9.

2. Lee, A.K.Y., IP, H.M.H., Wong, V.C.W. (1978) Mechanisms of maternal-fetal transmission of hepatitis B virus, J. Infect. Dis., 138, 668-71.

3. Papaevangelou, G., Hoofnagle, J.H. (1979). Transmission of hepatitis B virus infection by asymptomatic chronic $\mathrm{HBsAg}$ carrier mothers, Pediatrics, 63, 602-605.

4. Molica, F., Musumeci, S., Rugolo, S., Mattina, T. (1979). A prospective study of 18 infants of chronic HBsAg mothers, Arch. Dis. Childh. 54, 750-754.

5. Barin, F., Perrin, J., Chotard, J. et al. (1981). Cross-sectional and longitudinal epidemiology of hepatitis B in Senegal, Prog. Med. Virol. 27, 148-167.

6. Barin, F. Goudeau, A., Denis, F., et al. (1982). Immune response in neonates to hepatitis B vaccine, Lancet. i. 251-253.

7. Leichtner, A.M., Jeanne Leclair, Goldmann, D.A., et al. (1981). Horizontal nonparental spread of hepatitis B among children, Ann. Intern. Med. 94, 346-349.

8. Adamowicz, P., Gerfaux, G., Platel, A., et al. (1981). Largescale production of a hepatitis $B$ vaccine. In: Maupas, $\mathrm{P}$. Geusry, P., eds. Hepatitis B vaccine. Inserm Symposium No. 18. Amsterdam' Elsevier/North Holland, Bio-medical Press, $37-49$.

9. Szmuness, W., Cladd E. Stevens, Harley, E.J., et al. (1980). Hepatitis B vaccine. Demonstration of efficacy in a controlled clinical trial in a high-risk population in the United States, $N$. Engl. J. Med. 303, 833-841.

10. Mulley, A.G., Silverstein, M.D., Dienstag, J.L. (1982). Indications for use of hepatitis B vaccine, based on costeffectiveness analysis, N. Engl. J. Med., 307, 644-652. 